\title{
A Confront on Cancer allied Diabetic Patients
}

\author{
Arun Kumar $\mathbf{R}^{1 *}$, Sathish Kumar $\mathbf{D}^{2}$ and Nishanth $\mathbf{T}^{1}$ \\ ${ }^{1}$ Department of Biochemistry \& Bioinformatics, Gitam Institute of Science, GITAM University, Visakhapatnam, India \\ ${ }^{2}$ Department of Biotechnology, University of Hyderabad, Hyderabad, India
}

\begin{abstract}
Insulin resistance, hyperinsulinemia and changes in signaling of different hormones associated with diabetes may affect the risk of breast cancer. We reviewed epidemiologic studies of the association between and risk of different types of cancers and the available evidence on the role of certain mediators of an association between diabetes and cancer. Many evidences supports the modest association between type 2 diabetes and the risk of cancer, the mechanisms underlying an association between diabetes and cancer risk remain unclear, particularly because the 2 diseases share several risk factors, including obesity, a sedentary lifestyle. Although the metabolic syndrome is closely related to diabetes and embraces additional components that might influence cancer risk.
\end{abstract}

Keywords: Diabetes; Insulin; Liver; Pancreatic cancer; Carcinoma; Endometrial cancer; Tumor; Hormone; Obesity; Radiation therapy

Abbreviations: NASH: Nonalcoholic Steatohepatitis; HCC: Hepatocellular carcinoma; BMI: Body Mass Index; TURBT: Trans Urethral Resection of Bladder Tumor.

\section{Introduction}

People with Diabetes tend to have high levels of the blood-sugarregulating hormone insulin $[1,2]$ as well as related hormones called insulin-like growth factors. Those hormones cause cells to grow and spread, and that may include cancer cells. About $80 \%$ of cancer patients have glucose intolerance or frank diabetes [3]. People with diabetes [4] have high blood sugar because their body cannot move sugar into fat, liver and muscle cells to be stored for energy. This is because either:

- Their pancreas does not make enough insulin

- Their cells do not respond to insulin normally [5]

There are three major types of diabetes. The causes and risk factors are different for each type

Type 1 diabetes can occur at any age, but it is most often diagnosed in children, teens, or young adults. In this disease, the body makes little or no insulin. Daily injections of insulin are needed. The exact cause is unknown [6].

Type 2 diabetes is the commonest form of diabetes. It most often occurs in adulthood, but teens and young adults are now being diagnosed with it because of high obesity rates. Many people with type 2 diabetes do not know they have it [7].

Gestational diabetes is high blood sugar that develops at any time during pregnancy in a woman who does not have diabetes.

People are now aware that the lack of physical activity that plagues the globe is directly related to the increase in obesity. Obesity has been linked to health problems such as heart disease and type 2 diabetes. People with lower muscle mass on their bodies have increased risk of developing insulin resistance, which put them at risk of developing diabetes. So, building muscles specifically could help keep diabetes away the fact that the muscle plays an important role in glucose breakdown, thus affecting the body's ability to manage blood glucose level [8].

People with diabetes [9] have twice the risk of cancers of liver [10], pancreas and the uterine lining and are at a greater risk for colorectal, breast and bladder cancers than the normal population. A link to other cancers is inconclusive at present. High insulin levels, high glucose levels and chronic inflammation often seen in diabetes may influence cancer development [11].

Present review converses on cancers in diabetic patients, mainly focusing on liver cancer, pancreatic cancer, endometrial cancer, colorectal cancer and bladder cancer.

\section{Liver Cancer}

Liver cancer (Hepatocellular carcinoma) is a cancer [12,13] arising from the liver. It is also known as primary liver cancer or hepatoma. The liver is made up of different cell types such as bile ducts, blood vessels, and fat-storing cells. Liver cells (hepatocytes) make up $80 \%$ of the liver tissue. Thus, the majority of primary liver cancers over 90\%-95\%arises from liver cells and is called hepatocellular cancer or carcinoma [14]. Chronic infection with hepatitis B and C virus $[15,16]$, alcohol consumption $[17,18]$ and cirrhosis of the liver are recognized risk factors for primary liver cancer. Patients with diabetes are at increased risk of developing primary liver cancer and perhaps cancers of the biliary tract. Patients with insulin-dependent diabetes mellitus and those with non-insulin-dependent diabetes mellitus differ in their risk for primary liver cancer and the risk is also affected by the type of diabetes treatment [19]. Diabetes can be the result of metabolic syndrome, and this increases the risk of nonalcoholic steatohepatitis (NASH) [20]. NASH can lead to various forms of liver cancer such as Acute Liver Failure, Abnormal Liver enzymes, and Hepatocellar Carcinoma. i.e., acute liver failure can be associated with diabetes [21]. This is the quick deterioration of the liver that is followed by or linked

${ }^{*}$ Corresponding author: Arun Kumar R, Department of Biochemistry, Gitam Institute of Science, Gitam University, Visakhapatnam, India, E-mail: arunram88@ gmail.com

Received November 02, 2011; Accepted December 19, 2011; Published December 21, 2011

Citation: Arun Kumar R, Sathish Kumar D, Nishanth T (2011) A Confront on Cancer allied Diabetic Patients. J Carcinogene Mutagene 2:126. doi:10.4172/21572518.1000126

Copyright: (C) 2011 Arun Kumar R, et al. This is an open-access article distributed under the terms of the Creative Commons Attribution License, which permits unrestricted use, distribution, and reproduction in any medium, provided the original author and source are credited. 
to liver cancer [22-24]. Abnormal liver enzymes can be found in the blood as a direct result of cholesterol-reducing medicine. This medicine is used to control symptoms of diabetes. Hepatocellar Carcinoma (HCC) is a type of liver cancer greatly associated with diabetes. A study done by The American Association for the Study of Liver Diseases found that hyperinsulinemia is a possible reason for the increase of HCC in diabetic patient [25]. Particularly type 2 diabetes and cancer [26-28] share many risk factors. Some medications or drugs [29-31] used to treat hyperglycemia are associated with either an increased or reduced risk of cancer. Cancer and diabetes are diagnosed within the same individual more frequently than would be expected by chance, even after adjusting for age [32,33]. Both diseases are complex, with multiple subtypes. Diabetes is typically divided into 2 major subtypes, type 1 and type 2, along with less common types, whereas cancer is typically classified by its anatomic origin such as lymphoma, leukemia, lung, breast and liver cancer [34-37] within which there may be multiple subtypes. This is because insulin is produced by pancreatic $\beta$ cells and then transported via the portal vein to the liver. Both the liver and the pancreas are exposed to high concentrations of endogenously produced insulin. Diabetes-related factors including steatosis, nonalcoholic fatty liver disease, and cirrhosis may also enhance susceptibility to liver cancer [38-41]. Various symptoms of liver cancer [42-45] are Ascites ,Jaundice, Fever, Fatigue, Nausea ,Abdominal pain ,Loss of appetite, Weight loss ,Pain in the back or abdomen or around the right shoulder blade, A hard lump just below the rib cage, Dark-coloured urine ,Internal bleeding . The treatments for liver cancer are Surgery, Radiation therapy, Chemotherapy and Percutaneous ethanol injection [46-48]. The new types for liver cancer treatment still in clinical trials are Hyperthermia therapy and Biologic therapy. So, the Patients with diabetes are at increased risk of developing primary liver cancer [4952].

\section{Pancreatic Cancer}

Diabetes is a disease in which the body does not make or properly use a pancreatic hormone called insulin. Insulin helps the body utilize glucose efficiently. Normally, insulin allows glucose to enter cells to be used for energy. In people with diabetes, either the body does not produce enough insulin or the amount that is produced is not fully effective. Instead of entering cells, the glucose remains in the blood resulting in high blood glucose levels. High blood glucose can lead to cell damage and long-term complications. In general pancreatic cancer is two times more likely to occur in people who have diabetes than in people who do not have diabetes. Type 2 diabetes is associated with being overweight and is caused when the body becomes less responsive to the action of insulin, leading to high blood sugar levels. Type 1 diabetes arises, often in childhood, when the insulin-producing cells in the pancreas are damaged, usually by an aberrant immune reaction [53]. In pancreatic cancer the cancer [54-56] patients who have diabetes for less than five years, it is unclear if the diabetes contributed to the cancer or if the precancerous cells caused the diabetes. Cutting all forms of sugar out of the diet will not result in the death of cancer cells because cancer cells cannot be starved [57,58]. Glucose is the basic food source for all cells, including cancer cells and is provided by eating foods containing carbohydrates. It may be necessary to avoid foods high in simple sugars. If the patient is experiencing weight loss unrelated to blood sugar control, it may be caused by cancer induced weight loss, called cancer cachexia [59,60]. Chemical changes in the body cause the breakdown of body fat and lean body mass to make energy for cancer and healthy cells [61]. Different types of treatment are available for patients with pancreatic cancer [62]. Some treatments are standard. Three types of standard treatment are used: Surgery are as total pancreatectomy, distal pancreatectomy. Whipple procedure Radiation therapy is a cancer treatment that uses high-energy $\mathrm{x}$-rays or other types of radiation to kill cancer cells or keep them from growing. There are two types of radiation therapy. They are Chemotherapy is a cancer treatment that uses drugs $[63,64]$ to stop the growth of cancer cells, either by killing the cells or by stopping them from dividing [65].

\section{Endometrial Cancer}

Endometrial cancer is the most common type of uterine cancer. Increased levels of estrogen appear to play a key role in endometrial cancer [66]. Estrogen helps stimulate the buildup of the lining of the uterus. High level of estrogen results in excessive endometrial growth and cancer [67-69]. Obesity also has an adverse effect on both the diabetes and endometrial cancer. Diabetes was independently associated with endometrial cancer. Elevated levels of circulating insulin were a mechanism. Through which diabetes imparted an excess risk of various kinds of cancers [70-72]. Diabetes in particular was associated to endometrial cancer to some extent. With an elevation in risk of endometrial cancer among both users and nonusers of unopposed estrogens and elevations in risk among diabetics in all bmi Strata would be expected, since the diagnosis of type 2 diabetes is preceded by a period of hyperinsulinemia regardless of a person's Body Mass Index (BMI). The general symptoms of endometrial cancer are Abnormal uterine bleeding, abnormal menstrual periods, Bleeding between normal periods before menopause, Vaginal bleeding or spotting after menopause, Extremely long heavy, or frequent episodes of vaginal bleeding after age 40,Lower abdominal pain or pelvic cramping, Thin white or clear vaginal discharge after menopause. Treatment options involve surgery, radiation therapy, and chemotherapy [73,74].

\section{Colorectal Cancer}

Colorectal cancer is a disease in which cells in the colon or rectum become abnormal and divide without control, forming a mass called a tumor [75,76]. Colorectal cancer cells may also invade and destroy the tissue around them. In addition, they may break away from the tumor and spread to form new tumors in other parts of the body.

Colorectal cancer is more likely to occur as people get older; Polyps are abnormal growths that protrude from the inner wall of the colon or rectum [77]. They are relatively common in people over age 50, a person who has already had colorectal cancer is at an increased risk of developing colorectal cancer a second time, and Ulcerative colitis is a condition that causes inflammation and sores (ulcers) in the lining of the colon. Increasing evidence from epidemiologic studies suggests that cigarette smoking; particularly long-term smoking increases the risk of colorectal cancer. People with diabetes have a greater chance of developing colon cancer. They also tend to have lower survival rates and higher recurrence rates. Better blood sugar control would mean lower insulin levels, which might affect colon cancer risk. Obesity is also a risk factor for both diabetes and colon cancer. Association of type 2 diabetes with colon and rectal cancer [78] incidence among men suggests that insulin use is associated with a slight, but not a substantially increased, risk of colorectal cancer among men with type 2 diabetes. Sometimes surgery is an option for a person whose colorectal cancer has spread 
Citation: Arun Kumar R, Sathish Kumar D, Nishanth T (2011) A Confront on Cancer allied Diabetic Patients. J Carcinogene Mutagene 2:126. doi:10.4172/2157-2518.1000126

Page 3 of 5

in a limited way outside of the intestine. Chemotherapy may be recommended before surgery in some cases [79-81].

\section{Bladder Cancer}

Diabetes mellitus may alter the risk of developing a variety of cancers, and their associations are biologically plausible [82]. Bladder cancer is a major health concern for older males in Western populations $[83,84]$. Bladder cancer is a cancer [85-87] that starts in the bladder wherein body part holds and releases urine. It is in the center of the lower belly area. It is a disease in which abnormal cells multiply without control in the bladder. Based on types of fluids consumed many observed development of bladder cancer. It is hypothesized that the dietary components of beverages may lead to the development of bladder cancer [88]. Standard diagnosis for bladder cancer is biopsy which is obtained during cystoscopy [89]. In some cancer cases patients are generally treated by removing only part of the bladder, and that procedure is followed by radiation, chemotherapy and immunological therapy [90-92]. Surgical therapy includes Trans Urethral Resection of Bladder Tumor (TURBT), partial or complete Cystectomy.

\section{Conclusion}

There is a significant association between diabetes, diabetes therapies and cancer. In general diabetes seems to be linked to a variety of cancers including liver, pancreatic, colorectal, endometrial and bladder cancer. The proposed mechanism of action includes hyperinsulinemia and the effects that insulin has on the IGF axis to promote survival and progression of early malignant cells by increasing tumor growth and decreasing cellular apoptosis. Several studies are available to elucidate a correlation with cancer and insulin, it is important to continue treating diabetes with insulin analogs in order to avert the long-term complications of the disease. Possible mechanisms for a direct link between diabetes and cancer include hyperinsulinemia, hyperglycemia, and inflammation. Healthy diet, physical activity, and weight management reduce the risk and improve outcomes of type 2 diabetes and some forms of cancer and should be promoted for all.

\section{References}

1. Ramachandra S (2011) Do we need yet Insulin? J Diabet Metabol 2: 0e4.

2. Ragheb R, Medhat AM (2011) Mechanisms of Fatty Acid-Induced Insulin Resistance in Muscle and Liver. J Diabetes Metab 2: 127.

3. Saini A, Devidayal, Verma S, Bhalla AK (2011) Comparative Efficacy of Once Daily Insulin Glargine with Twice Daily NPH Insulin in Children with Type 1 Diabetes. J Diabetes Metab 2: 124.

4. Joffe B, Distiller L, Landau S, Blacking L, Klisiewicz A (2010) Spectrum of Autoimmune Disorders in Type 1 Diabetes - A Cross-Sectional Clinical Audit. J Diabetes Metab 1: 112

5. http://www.ncbi.nlm.nih.gov/pubmedhealth/PMH0002194/

6. Higuchi C, Tone A, Iseda I, Tsukamoto K, Katayama A, et al. (2010) A Pregnant Patient with Brittle Type 1 Diabetes Successfully Managed by CSII Therapy with Insulin Aspart. J Diabetes Metab 1: 104

7. Ramachandra A, Snehalatha C, Vijay V (2002) Burden of Type 2 Diabetes and its Complications -The Indian Scenario. 83: 1471-1476.

8. http://www.fyiliving.com/diet/special-diets/diabetes-diet/diabetes-how-toliterally-run-away-from-it/

9. Gao S, Wang X (2009) Predicting Type 1 Diabetes Candidate Genes using Human Protein-Protein Interaction Networks. J Comput Sci Syst Biol 2: 133146.

10. Mi Z, Guo H, Markovic J, Kuo PC (2009) Characterization of Osteopontin
Binding Kinetics In MDA-MB231 Breast and SK-Hep-1 Liver Cancer Cells. J Cancer Sci Ther 1: 047-051.

11. http://www.livestrong.com/article/169096-cancers- related-to-diabetes/

12. Vitin AA, Martay K, Vater Y, Dembo G, Maziarz M (2010) Effects of Vasoactive Agents on Blood Loss and Transfusion Requirements During Pre- Reperfusion Stages of the Orthotopic Liver Transplantation. J Anesthe Clinic Res 1: 104.

13. Sudhakar A (2009) History of Cancer, Ancient and Modern treatment Methods. J Cancer Sci Ther 1: i-iv.

14. http://www.medicinenet.com/liver_cancer/page2.htm

15. Mira JA, López-Cortés LF, Vispo E, Tural C, Laguno M, et al. (2010) Concomitant Nevirapine Therapy is Associated with Higher Efficacy of Pegylated Interferon Plus Ribavirin among HIV/Hepatitis C Virus-Coinfected Patients. J AIDS Clinic Res 1: 112.

16. Mata RC, Mira JA, Rivero A, López-Cortés LF, Torres-Tortosa M, et al.(2010) Nevirapine-based Antiretroviral Therapy is Associated with Lower Plasma Hepatitis C Virus Viral Load among HIV/Hepatitis C Virus-Coinfected Patients. AIDS Clinic Res J1: 110.

17. Kolla BP, Bostwick JM (2011) Insomnia: The Neglected Component of Alcoho Recovery. J Addict Res Ther 2: 0e2.

18. Demarie D, Marletta G, De Vivo E, Rivela E, Bignamini E (2011) Long QT Syndrome (LQTS) in Opiate, Cocaine and Alcohol Addiction, with HIV+ / HCV+ Co-Infection in Antiretroviral Therapy (HAART). J Addict Res Ther 2: 114.

19. Adami HO, Chow WH, Olof Nyrén, Berne C, Linet M, et al. (1996) Excess Risk of Primary Liver Cancer in Patients with Diabetes Mellitus. J Natl Cancer Inst 88: $1472-1477$.

20. Messripour M (2011) A novel Enzyme Inhibition Assay for Screening of Type 1 Diabetes Mellitus. J Mol Biomark Diagn 2: 107

21. Jacobson JD, Midyett LK, Garg U, Sherman AK, Patel C (2011) Biochemica Evidence for Reduced Carnitine Palmitoyl Transferase 1 (CPT-1) Activity in Type 1 Diabetes Mellitus. J Diabetes Metab 2: 144.

22. Gayed IW, Wahba H, Wan D, Joseph U, Murthy R (2010) Effect of Y-90 SIRSpheres Therapy for Multiple Liver Metastases in a Variety of Tumors. J Cancer Sci Ther 2: 043-046.

23. Mukherjee S (2009) Antiviral Therapy for Hepatitis B in Preand Post-liver Transplant Patients. J Antivir Antiretrovir 1: 017-027.

24. Kumar V, Sahu NP, Pal AK, Jain KK, Kumar S, et al. (2011) Gelatinized and Non-Gelatinized Corn Starch Based Diet Influence the Fatty Acid Profile in the Liver of Tropical Freshwater Fish, Labeo Rohita. J Aquac Res Development 2: 106.

25. http://www.ehow.com/facts_5042858_diabetes-affects-liver.html

26. Singh RK, Sudhakar A, Lokeshwar BL (2011) From Normal Cells to Malignancy: Distinct Role of Pro-inflammatory Factors and Cellular Redox Mechanisms. J Cancer Sci Ther 3: 070-075.

27. Sai YRKM, Dattatreya A, Anand SY, Mahalakshmi D (2011) Biomarkers and their Role in Premonition, Interpretation and Treatment of Cancer. J Cancer Sci Ther R1: 002.

28. Naga Deepthi $\mathrm{CH}$, VVL Pavan Kumar A, Rameshbabu, Indirapriyadarshin U (2011) Role of Tumor Suppressor Protein p53 in Apoptosis and Cancer Therapy. J Cancer Sci Ther R1: 001.

29. Zhao Y, Haney MJ, Mahajan V, Reiner BC, Dunaevsky A, et al. (2011) Active Targeted Macrophage-mediated Delivery of Catalase to Affected Brain Regions in Models of Parkinson's Disease. J Nanomedic Nanotechnol S4: 003.

30. Dang Q, Reddy KR, Kasibthatla SR, Jiang T, Taplin F, et al. (2010) Discovery of Phosphonic Acid-Containing Desaminobenzimidazoles as Fructose 1,6-Bisphosphatase Inhibitors that are Suitable for Oral Delivery via Prodrugs. J Diabetes Metab 1: 105

31. Douroumis D (2011) Mesoporous silica Nanoparticles as Drug Delivery System J Nanomedic Nanotechnol 2: 102e.

32. Ferreira AK, Meneguelo R, Neto SC, Chierice GO, Maria DA (2011) Synthetic 
Citation: Arun Kumar R, Sathish Kumar D, Nishanth T (2011) A Confront on Cancer allied Diabetic Patients. J Carcinogene Mutagene 2:126. doi:10.4172/2157-2518.1000126

Page 4 of 5

Phosphoethanolamine Induces Apoptosis Through Caspase-3 Pathway by Decreasing Expression of Bax/Bad Protein and Changes Cell Cycle in Melanoma. J Cancer Sci Ther 3: 053-059.

33. Wilkinson A, Bian L, Khalil D, Gibbons K, Wong PF, et al. (2011) Type 1 Diabetic Children and Siblings Share a Decrease in Dendritic Cell and Monocyte Numbers but are Differentiated by Expansion of CD4+T Cells Expressing IL-17. J Clin Cell Immunol S2: 001.

34. Zhao Y (2011) Autoimmunity and Therapeutic Challenges of Type 1 Diabetes. Translational Medic 1: 104e.

35. Nellithady GS, Anila K, Kumar KK, Kaveri H (2010) Lack of Association of Chronic Liver Disease in Patients with Oral Lichen Lanus. J Carcinogene Mutagene 1: 113.

36. Grundmann O (2010) The Gut Microbiome and Pre-systemic Metabolism: Current State and Evolving Research. J Drug Metabol Toxicol 1: 104.

37. Shimoda M (2010) Surgical Site Infection Rate of PDS-II and Dermabond Versus Vicryl and Silk in Major Abdominal Surgery Using the Pig Liver Resection Model. J Clin Exp Dermatol Res 1: 110.

38. Vinken M (2011) Mathieu Vinken's Work on the Role of Connexin-related Signalling in Hepatic Homeostasis and its Relevance for Liver-based In vitro Modelling. Pharm Anal Acta 2: 101e.

39. Hassan GM, Mazher KHM (2011) Genotoxicity and Histopathological Studies on the Liver, Kidney and Lymphocytes of Male Rats Fed on Diet Containing Waste Fat Released from Chicken During Grilling Process. J Cytol Histol 2: 111.

40. Edward G, David MH, Archer MC, Richard MB, Gapstur M, et al (2010) Diabetes and Cancer: A Consensus Report 60: 207-221.

41. Ying J, Quanjun W, Jinglan W, Songfeng W, Gang C, et al. (2008) Profiling of Phosphorylated Proteins in Human Fetal Liver. J Proteomics Bioinform 1: 437-457.

42. EL-Shenawy NS, El-Ahmary B, Al-Eisa RA (2011) Mitigating Effect of Ginger against Oxidative Stress Induced by Atrazine Herbicides in Mice Liver and Kidney. J Biofertil Biopestici 2: 107.

43. Polaniak R, Bułdak RJ, Jacheć W, Helewski K, Wojnicz R, et al. (2011) Long-term Exposure to Acetaminophen is a Crucial for Activity of Selected Antioxidative Enzymes and Level of Lipid Peroxidation Process in Rat Liver. $J$ Bioequiv Availab 3: 182-186.

44. Mahran AA, Husam Eldien HO, Abd El-Mawla AMA, Attia AM (2011) Protective Effect of Zinc (Zn) on the Histology and Histochemistry of Liver and Kidney of Albino Rat Treated with Cadmium. J Cytol Histol 2: 123.

45. Harring TR, Nguyen NT, Goss JA, O'Mahony CA (2011) Human T-Cell Lymphoma Virus-Positive Allograft Used For Effective Orthotopic Liver Transplantation: A Case Report and Review of the Literature. J Transplant Technol Res 1: 102.

46. Yang X, Li Z, Su Z, Davis K, Chen T, et al. (2011) Urinary Micrornas as Noninvasive Biomarkers for Acetaminophen-Induced Liver Injury. J Postgenom Drug Biomark Develop 1: 101.

47. Castellanos MI, Seijas OR, González D, Ronquillo M, del Rosario Abreu M, et al. (2011) Immune Alterations in Liver Cirrhosis: Its Relationship with Etiology, Child Pugh Stage and Malnutrition. J Nutrition Disorder Ther 1: 101.

48. Kivity S, Ben-Haim M, Guranda L, Olchovsky D (2011) Shocking Liver. Rheumatology 1: 103. http://www.indian-medical-center.com/liver-cancer.html

49. Sapisochin G, Charco R (2011) Salvage Liver Transplantation for HCC: An Old Story without Consensus? J Transplant Technol Res 1: 106e.

50. Lins Kusterer LEF (2011) Oral Diseases and Liver Pre and Post- Transplantation Disorders. J Transplant Technol Res S1: 001.

51. Amin J, De Lazzari E, Emery S, Martin A, Martinez E, et al. (2010) Simplification with Fixed-Dose Tenofovir-Emtricitabine or Abacavir-Lamivudine in Treatment Experienced, Virologically Suppressed Adults with Hiv Infection: Combined Analysis of Two Randomised, Non-Inferiority Trials Bicombo and Steal. J AIDS Clinic Res 1: 103.

52. http://www.reuters.com/article/2007/03/01/us-type-idUSCOL16258220070301
53. Shrihari TG (2011) Cancer Stem Cells - Therapeutic Boon! J Cancer Sci Ther 3: $197-200$.

54. Nguyen KT (2011) Targeted Nanoparticles for Cancer Therapy: Promises and Challenges. J Nanomedic Nanotechnol 2: $103 \mathrm{e}$.

55. Rosen JE, Yoffe S, Meerasa A, Verma M, Gu FX (2011) Nanotechnologyand Diagnostic Imaging: New Advances in Contrast Agent Technology. JNanomedic Nanotechnol 2: 115

56. Dronca RS, Markovic SN, Holtan SG, Porrata LF (2011) Neuroendocrineimmune Crosstalk and Implications for Cancer Therapy. J Cell Sci Ther 2: 102e.

57. Jasmine G, Yogeshwer S (2008) Prognostic Factors of Male Breast Cancer: Proteomic Approaches for Early Detection and Treatment. J Proteomics Bioinform 1: 112-127.

58. Daniel BS, Murrell DF (2010) Chronic Urticaria Resolving after Resection of Mucinous Breast Cancer. J Clin Exp Dermatol Res 1: 103.

59. Rosarin FS, Mirunalini S (2011) Nobel Metallic Nanoparticles with Nove Biomedical Properties. J Bioanal Biomed 3: 085-091.

60. http://www.pancan.org/section_facing_pancreatic_cancer/learn_about_pan_ cancer/diet_and_nutrition/Diabetes.php

61. Masayo Y, Kiyonaga F, Koji K, Setsuo H, Tadashi K (2009) The Proteomic Profile of Pancreatic Cancer Cell Lines Corresponding to Carcinogenesis and Metastasis. J Proteomics Bioinform 2: 001-018.

62. Anwunobi AP, Emeje MO (2011) Recent Applications of Natural Polymers in Nanodrug Delivery. J Nanomedic Nanotechnol S4: 002.

63. Torzewski J, Li K, Zimmermann O (2011) Road Map to Drug Discovery and Development-Inhibiting C-reactive protein for the Treatment of Cardiovascular Disease. J Bioequiv Availab S1.

64. http://www.cancer.gov/cancertopics/pdq/treatment/pancreatic/Patient/page4

65. Tebeu PM, Verkooijen HM, Popowski Y, Bouchardy C, Ludicke F, et al. (2011) Impact of External Radiotherapy on Survival after Stage I Endometrial Cancer: Results from a Population-Based Study. J Cancer Sci Ther 3: 041-046.

66. http://www.omicsonline.org/1948-5956/JCST-03-041.pdf

67. Sinnathamby G, Zerfass J, Hafner J, Block P, Nickens Z, et al. (2011) EDDR1 is a Potential Immunotherapeutic Antigen in Ovarian, Breast, and Prostate Cancer. J Clin Cell Immunol 2: 106.

68. Khan DR (2010) The Use of Nanocarriers for Drug Delivery in Cancer Therapy. J Cancer Sci Ther 2: 058-062.

69. Hill EJ, Sharma RA (2011) Multi-modality Therapy of Hepatic Metastases from Colorectal Carcinoma: Optimal Combination of Systemic Chemotherapy with Radio-embolization. J Nucl Med Radiat Ther 2: 108.

70. Kennedy A, Dezarn W, Weiss A (2011) Patient Specific 3D Image-Based Radiation Dose Estimates for 90Y Microsphere Hepatic Radioembolization in Metastatic Tumors. J Nucl Med Radiat Ther 2: 111.

71. Meyer JE, Cohen SJ (2011) Beyond First-Line Therapy: Combining Chemotherapy and Radioembolization for Hepatic Colorectal Metastases. J Nucl Med Radiat Ther 2: 103.

72. Liu DM, Cade D, Klass D, Loh C, McWilliams JP, et al. (2011) Interventional Oncology - Avoiding Common Pitfalls to Reduce Toxicity in Hepatic Radioembolization. J Nucl Med Radiat Ther 2: 106.

73. Babette S, Jennifer AD, Deirdre AH, Shirley AB, Lynda FV, et al. (2007) Diabetes and Endometrial Cancer: An Evaluation of the Modifying Effects of Other Known Risk Factors. Am J Epidemiol 167: 607-614.

74. http://www.ncbi.nlm.nih.gov/pubmedhealth/PMH0001908/

75. Manace LC (2011) To Test or Not To Test: Colon Cancer Pharmacogenetics and Predisposition Genetics. J Pharmacogenom Pharmacoproteomics 2: e101.

76. Basciano CA, Kleinstreuer C, Kennedy AS (2011) Computational Fluid Dynamics Modeling of $90 \mathrm{Y}$ Microspheres in Human Hepatic Tumors. J Nucl Med Radiat Ther 2: 112.

77. Bernstein C, Payne CM, Bernstein H (2011) Bile Acids: Promoters or 
Citation: Arun Kumar R, Sathish Kumar D, Nishanth T (2011) A Confront on Cancer allied Diabetic Patients. J Carcinogene Mutagene 2:126. doi:10.4172/2157-2518.1000126

Carcinogens in Colon Cancer? J Carcinogene Mutagene 2: 101e.

78. Schneider R, Fürst A (2011) Open or Laparoscopic Total Mesorectal Excision for Rectal Cancer what is the Optimal Approach? J Gastrointest Digest Sys 1: e101.

79. http://www.cancer.gov/cancertopics/factsheet/detection/colorectal-screening

80. http://www.msnbc.msn.com/id/44706041/ns/health-cancer/t/diabetes-againlinked-colon-cancer-risk/\#.TtXCIFmOAwo

81. Rathi Manohar (2010) Type 2 Diabetes Linked to Colorectal Cancer.

82. Steven S. Coughlin, Eugenia E. Calle, Lauren R. Teras, Jennifer Petrelli, et al. (2004) Diabetes Mellitus as a Predictor of Cancer Mortality in a Large Cohort of US Adults. American Journal of Epidemiology 159: 1160-1167.

83. Hsieh CL, Wang HE, Ker YB, Peng CC, Chen KC, et al. (2011) GC/MS Determination of N-butyl-N-(3-carboxypropyl) Nitrosamine (BCPN) in Bladder Cancers - The Skewed Molecular Interaction Caused Retention Time Shift. J Anal Bioanal Techniques 1: 115.

84. Brinkman M, Zeegers MP (2008) Nutrition, Total Fluid and Bladder Cancer, Scand J Urol Nephrol Suppl. 218: 25-36.

85. Burrill J, Hafeli U, Liu DM (2011) Advances in Radioembolization- Embolics and Isotopes. J Nucl Med Radiat Ther 2:107.
86. Sangro B, Iñarrairaegui M (2011) Radioembolization for Hepatocellular Carcinoma: Evidence-Based Answers to Frequently Asked Questions. J Nucl Med Radiat Ther 2: 110.

87. Anthony L (2011) Neuroendocrine Hepatic Tumors: Summary of Patient Selection, Response and Toxicity of Radioembolization in 281 Patients. J Nucl Med Radiat Ther 2: 104

88. Martha L. Slattery, Dee W. West, Linda M. Robiso (1988) Fluid intake and bladder cancer in UTAH International Journal of Cancer 42: 17-22.

89. Sami WM, Richard LH (2008) Can posthysterectomy cystoscopy be utilized as a screening test for bladder cancer? Ger Med Sci 6: 1-2.

90. Ettorre GM, Vennarecci G, Santoro R, Miglioresi L, Lepiane P, et al. (2011) Experiences in Hepatic Surgery and Transplantation after Radioembolization. J Nucl Med Radiat Ther 2: 109.

91. Lowe K, Jeyarajah DR (2011) Integration of Surgery and Radioembolization in Treatment of Hepatic Tumors. J Nucl Med Radiat Ther 2: 105.

92. Vouche M, Vanderlinden B, Delatte P, Lemort M, Hendlisz A, et al. (2011) New Imaging Techniques for 90Y Microsphere Radioembolization. J Nucl Med Radiat Ther 2: 113. 